Article

\title{
Assessment of the Potential Use of Young Barley Shoots and Leaves for the Production of Green Juices
}

\author{
Agata Blicharz-Kania ${ }^{1}$, Dariusz Andrejko ${ }^{1}$, Franciszek Kluza ${ }^{1}$, Leszek Rydzak ${ }^{1, *}$ and \\ Zbigniew Kobus ${ }^{2}$ (1) \\ 1 Department of Biological Bases of Food and Feed Technologies, University of Life Sciences in Lublin, \\ 20-612 Lublin, Poland \\ 2 Department of Technology Fundamentals, University of Life Sciences in Lublin, 20-612 Lublin, Poland \\ * Correspondence: leszek.rydzak@up.lublin.pl; Tel.: 81-531-9650
}

Received: 9 June 2019; Accepted: 19 July 2019; Published: 21 July 2019

\begin{abstract}
It is possible to use the aboveground parts of barley, which are cultivated as a forecrop. They are often simply composted or dried for bedding. It is worth trying other more effective methods of processing aboveground biomass. The aim of this study was to preliminary investigate the possibility of using young barley leaves and shoots for the production of green juice with potential health properties. The material was collected at days 7, 14, 21, and 28 after plant emergence. The length and strength of the shoots were measured and the pressing yield was calculated. The $\mathrm{pH}$ value and the content of protein, chlorides, and reducing sugars were also determined. The juice was additionally subjected to pasteurisation and freezing, and changes in $\mathrm{pH}$ and chlorophyll content occurring during storage were determined. The pressing yield of young barley leaves and shoots was estimated to be between $69 \%$ and $73 \%$. The product was characterised by a high content of total protein $\left(34.45 \%-51.81 \%_{\text {d.w. }}\right)$ and chlorophylls $\left(6.62 \mathrm{mg} \cdot \mathrm{g}^{-1}\right)$. The chlorophyll content declined during barley juice storage. Pasteurisation of the juice from young barley leaves does not induce statistically significant changes in the $\mathrm{pH}$ of the juice, but reduces the chlorophyll content. Our results revealed that the most effective way to preserve the green juice is by freezing. This process does not induce changes in juice acidity and only slightly reduces the chlorophyll content during storage of the product.
\end{abstract}

Keywords: juice; barley; pressing; protein; chlorophylls; green food

\section{Introduction}

In order to improve the soil quality and protect it from weeds and, consequently, obtain a better crop of the cultivated plant, producers often use forecrop cultivation. Depending on what kind of plant will be grown, an appropriate forecrop will be selected. For cereals, the best options are root crops (mainly potatoes), legumes, or rapeseed. However, when growing vegetables, such as tomatoes, carrots, or white cabbage, it is better to use a cereal forecrop, and rye, wheat, or barley can be used [1]. These cereals can be used via two techniques. The first method involves ploughing whole plants and using them as a fertilizer. Plants that are a forecrop can also be cut. Then, only roots and postharvest residues are ploughed. In the case of the latter method, it is possible to continue using the green parts of the plants, which are often simply composted or dried for bedding.

Recently, products from young barley leaves and shoots have gained popularity. They are available in a variety of forms, i.e., juice, tablets, or powder. Young parts of plants are a source of phenolic acids and many vitamins, e.g., C, E, and B group vitamins. Additionally, barley grass contains substantial amounts of carotenoids, folic acid, calcium, iron, magnesium, potassium, zinc, and copper. Importantly, products obtained from cereal leaves and shoots can be used as supplements 
in a high-protein diet. Barley grass contains approximately $30 \%$ of protein in dry matter [2-4]. The chemical index of nutritional value (Chemical Score, CS) is $41.44 \%$ (Methionine) [5]. Barley shoots and leaves are also a source of chlorides. Naturally occurring chlorides exert a beneficial effect on organism function. Chloride ions participate in the regulation of water, as well as electrolyte metabolism and maintaining acid-base balance [6].

One of the most important active compounds in "green food" is chlorophyll. Seed plants contain type A and B chlorophylls, which differ according to the type of substituent on the second pyrrole ring. However, these pigments are unstable. Many factors, e.g., UV radiation or $\mathrm{pH}$ and temperature changes, cause chlorophyll degradation in food products. Chlorophylls are a valuable source of magnesium; they can also improve metabolism and eliminate unpleasant mouth odours. Additionally, they have antibacterial and anti-inflammatory properties, remove toxins from the liver and blood [7-11], and even act as a haemoglobin substitute [12].

The consumption of green juices has therapeutic properties: it exerts an antidiabetic effect, regulates blood pressure, strengthens immunity, protects the liver, and has anti-acne and antidepressant activities. It also improves the function of the digestive tract and prevents hypoxia, cardiovascular diseases, fatigue, and constipation. Additionally, it alleviates atopic dermatitis and has anti-inflammatory, antioxidant, and anticancer effects [4]. Kubatka et al. [13] have demonstrated positive changes in tumour cells in rats treated with juice from young barley leaves. A significantly more pronounced effect of the therapeutic treatment was observed in a study group receiving a diet supplemented with the juice. It has also been confirmed that supplementation of the diet with barley leaf powder can relieve the clinical symptoms of diabetes [14]. Additionally, barley grass contains substantial amounts of dietary fibre (mainly an insoluble fraction), which has a positive effect on metabolism through regulating the appetite and, thus preventing the development of overweight. Son et al. [3] recommend enrichment of the diets of young children using valuable nutrients from young barley leaves.

Products from young barley leaves have been used in East Asia for a long time. Currently, they are available in supermarkets, as well as online, in the United States and many European countries. The increase in consumer awareness has contributed to an appreciation of the health benefits of "green food" [8]. A number of products based on young cereal leaves are recommended as dietary supplements and, hence, are currently being manufactured to be purchased in pharmacies.

There is a paucity of scientific publications confirming the health-promoting properties of the juice from young barley leaves. There are also no preliminary investigations describing the impact of production and processing on the quality of green juices. Furthermore, the relationship between the date of raw material harvesting and the pressing process, as well as the content of nutrients-including proteins-in the juice, has not yet been analysed. Another unexplored area is the changes occurring in the chlorophyll content of barley juice, depending on the thermal treatment. Knowledge of these relationships has great practical significance as it provides information on methods for the acquisition of a product with a high nutritional value and, at the same time, ensures the longest possible growth period for the plant (and, thus, the greatest mass of roots to be used as forecrop).

The aim of this work was to preliminary examine the efficiency of the process of pressing green juice from young barley leaves and shoots and to determine the chemical composition of the product obtained. An additional goal of the research was to compare the effect of preservation methods like pasteurization and freezing on the chlorophyll content and $\mathrm{pH}$ of barley juice.

\section{Materials and Methods}

\subsection{Research Material}

Barley grain cv. Kangoo was used for the investigations. The seeds, weighing $5 \mathrm{~kg}$, were sown under laboratory conditions (Figure 1). No fertilisation was applied during the cultivation. The material was collected at days 7, 14, 21, and 28 after plant emergence. The crop area was divided into four parts, and these four parts were then divided again into 12 smaller ones. Three parts from the 
whole field were chosen at random for each series of investigation (different harvest time: 7, 14, 21, and 28 days). Each sample of shoots and leaves of young barley for juice production weighed $200 \mathrm{~g}$.

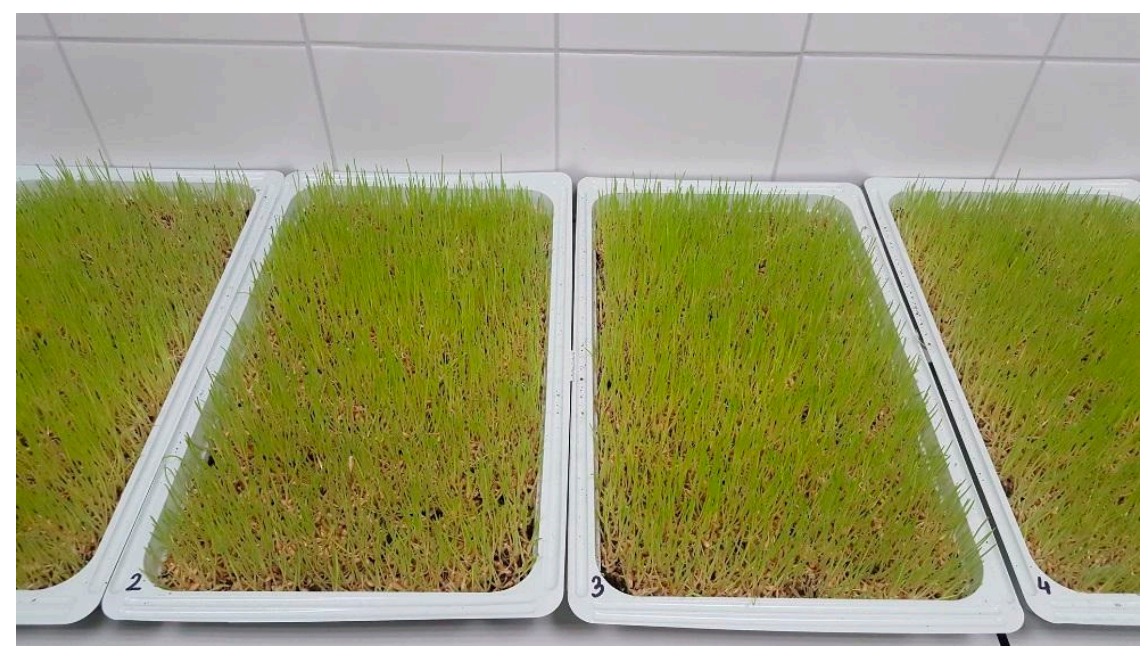

Figure 1. Cultivation of barley.

\subsection{Measurement of Physical Properties}

Samples without mechanical damage were selected for determination of the length and strength of the barley. The length of five barley shoots was measured with the use of a calliper to the nearest $0.01 \mathrm{~mm}$. The shoot strength was determined by applying a uniaxial tensile test to the leaves. The test was carried out using a Zwick/Roell Z0.5 materials testing machine (Zwick.Roell AG, BT1-FR0.5TN.D14, Ulm, Germany) equipped with a measuring head at a maximum force of $50 \mathrm{~N}$ (travel speed $=50 \mathrm{~mm} \cdot \mathrm{min}^{-1}$ ). Tensile strength was applied to the material until rupture. TestXpert II software (Zwick/Roell AG, Ulm, Germany) was used to assess the force required for destruction of the barley grass.

\subsection{Pressing}

The juice was squeezed from barley grass (with a weight of $200 \mathrm{~g}$ for each repetition) using a press designed for pressing green plant leaves, i.e., Manual Juicer BL-30 (BioChef, Byron Bay, NS, Australia).

The pressing efficiency was calculated using the following equation:

$$
W_{j}(\%)=\frac{M_{j}}{M_{i}} \cdot 100
$$

where:

$$
\begin{aligned}
& W_{j} \text { - pressing yield, \%; } \\
& M_{j} \text {-mass of juice after pressing, } \mathrm{kg} ; \\
& M_{i} \text { - mass of input material, } \mathrm{kg} .
\end{aligned}
$$

\subsection{Preserving Juice}

The juice obtained in the first harvest term (at seven days after plant emergence) was additionally subjected to pasteurisation for $10 \mathrm{~min}$ at $75^{\circ} \mathrm{C}$ and freezing. Immediately after the thermal treatment, the product was cooled (in a blast chiller-freezer) to $3^{\circ} \mathrm{C}$. The other batch of juice was blast-frozen to a temperature of $-18{ }^{\circ} \mathrm{C}$. The material was stored under appropriate conditions, i.e., $4^{\circ} \mathrm{C}$ in the case of the unprocessed (UJ) and pasteurised (PJ) juice and $-18^{\circ} \mathrm{C}$ in the case of the frozen juice (FJ). The study material was analysed after three (UJ and PJ) and seven (UJ, PJ, and FJ) storage days. 


\subsection{Determination of $p H$}

Juice samples were placed in $50 \mathrm{~mL}$ beakers and the $\mathrm{pH}$ was recorded with a $\mathrm{pH}$ meter (model 780, Metrohm AG, Herisau Switzerland).

\subsection{Measurement of Total Protein Content}

The determinations were carried out using the Kjeldahl method and a Foss Kjeltec 8400 automatic distiller (Foss Anatytical AB, Höganäs, Sweden). The total protein content was calculated using a 6.25 conversion factor.

\subsection{Determination of the Chloride Content}

The chloride content was determined with the Mohr method using a TitraLab AT1000 Series automatic titrator (HACH Company, Willstätterstraße, Germany). The solution was titrated with a $0.1 \mathrm{~N}$ silver nitrate solution. The chloride content was given as $\mathrm{g}$ in $100 \mathrm{~g}_{\mathrm{f} . \mathrm{j} .}$ (of fresh juice).

\subsection{Determination of the Content of Reducing Sugars}

The Lane-Eynon method was used to determine the content of reducing sugars. The material was extracted and deproteinised. The content of reducing sugars was determined in the obtained liquid by direct hot titration of a specific copper salt with the analysed sugar solution (against methylene blue as an indicator of the end of the reaction) $[15,16]$.

\subsection{Determination of Dry Matter Content}

The moisture content of the research material was measured by drying $3 \mathrm{~g}$ of juice at $105^{\circ} \mathrm{C}$ for 3 h. The measurements were carried out in triplicate.

\subsection{Measurement of Chlorophyll Content}

The juice was analysed for the content of chlorophylls A and B. The pigments were extracted with methyl alcohol. The chlorophyll content was measured using a UV-vis Helios Omega 3 spectrophotometer (Thermo Scientific, England). The measurement consisted of the determination of the absorbance (A) at different wavelengths ( $\lambda$ ): 650 and $665 \mathrm{~nm}$ [17]. Next, the content of chlorophylls $A$ and $B$ and the total chlorophyll content were calculated with Equations (2)-(4):

Chlorophyll A content $\left(\mathrm{C}_{\mathrm{chl}(\mathrm{a})}\right)$ :

$$
\mathrm{C}_{\mathrm{chl}(\mathrm{a})}=16.5 \cdot \mathrm{A}_{(665)}-8.3 \cdot \mathrm{A}_{(650)}
$$

Chlorophyll B content $\left(\mathrm{C}_{\mathrm{chl}(\mathrm{b})}\right)$ :

$$
\mathrm{C}_{\mathrm{chl}(\mathrm{b})}=33.8 \cdot \mathrm{A}_{(650)}-12.5 \cdot \mathrm{A}_{(665)}
$$

Total chlorophyll content (C):

$$
\mathrm{C}=4.0 \cdot \mathrm{A}_{(665)}+25.5 \cdot \mathrm{A}_{(650)}
$$

where:

$A_{(650)}=$ absorbance at a $650 \mathrm{~nm}$ wavelength;

$A_{(665)}=$ absorbance at a $665 \mathrm{~nm}$ wavelength.

The chlorophyll content was calculated in $\mathrm{mg}^{-1} \mathrm{~g}^{-1}$, taking into account the sample weight.

\subsection{Statistical Analysis}

The data were analysed statistically. A significance level of $\alpha=0.05$ was assumed for inference. The analysis was carried out using ANOVA (StatSoft Polska, Poland) with post hoc tests for homogeneous 
groups based on Tukey's test. These groups comprised means between which no statistically significant difference was found at the assumed significance level, $\alpha$.

The determinations were carried out in triplicate, except for leaf length and strength tests, which were repeated five times.

\section{Results and Discussion}

\subsection{Characterisation of the Physical Traits of the Raw Material}

Changes in the length of the barley shoots relative to the harvest date are shown in Table 1.

Table 1. Properties of the raw material relative to the harvest time of barley leaf harvesting.

\begin{tabular}{cccccc}
\hline Harvest Time (Day) & $\mathbf{7}$ & $\mathbf{1 4}$ & $\mathbf{2 1}$ & $\mathbf{2 8}$ & $p$-Value \\
\hline Length of leaves $(\mathrm{mm})_{\text {Strength of leaves }(\mathrm{N})}$ & $9.08 \pm 1.14^{\mathrm{a}}$ & $15.48 \pm 1.26^{\mathrm{b}}$ & $17.58 \pm 1.44^{\mathrm{bc}}$ & $19.53 \pm 1.35^{\mathrm{c}}$ & $<0.0001$ \\
$\mathrm{a}, \mathrm{b}, \mathrm{c}, \mathrm{d}$ & Means in the same line denoted by different letters were significantly different. The results are expressed as \\
mean $\pm \mathrm{SD}(n=5)$. & $3.27 \pm 0.45^{\mathrm{ab}}$ & $3.20 \pm 0.39^{\mathrm{ab}}$ & $3.01 \pm 0.69^{\mathrm{b}}$ & 0.0144 \\
\hline
\end{tabular}

The largest gain in the length of barley shoots was noted within seven days after emergence. In the following days, the rate of shoot growth declined. There were no statistically significant differences in the length of shoots between the material harvested at day 21 and day 28 after emergence. The length of shoots collected on day 21 and day 28 was 17.58 and $19.53 \mathrm{~cm}$, respectively. The height of the plants was characteristic of unfertilised crops [18-20].

The strength of the barley shoots decreased over time. However, there were only significant changes in the tensile strength of the shoots in the material collected on day 28 of growth (in comparison to the material collected on day 7). Changes in the strength of cereal shoots are associated with the chemical composition, which is modified during plant growth [18].

\subsection{The Pressing Efficiency}

The effect of the harvest date on the pressing yield is shown in Figure 2.

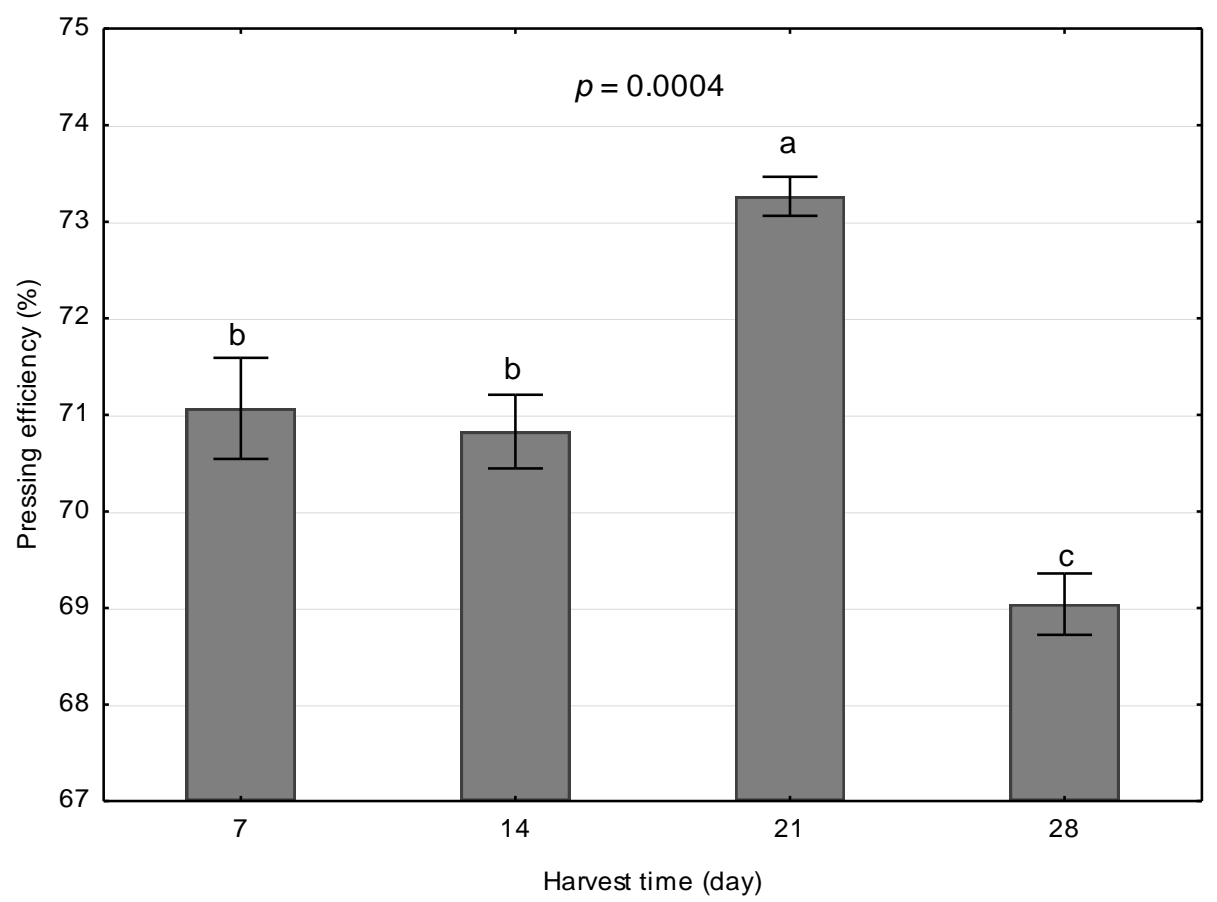

Figure 2. Pressing yield of the barley shoot and leaf juice relative to the harvest date. 
The pressing yield ranged from $69.04 \%$ to $73.26 \%$. It was obtained from 137 to $146 \mathrm{~mL}$ of juice (depending on the time of harvest). The highest value was noted during the processing of material harvested on cultivation day 21. The longer period of cultivation was associated with a statistically significant drop in the pressing yield. The pressing yield of barley leaves collected on day 28 was estimated at $69.4 \%$. These results are consistent with data obtained by other authors. Paulíčková et al. [2] reported a pressing yield of $68 \%$ in a study that involved the extraction of juice from barley shoots. The decline in the pressing yield accompanying the longer harvesting period is probably caused by changes in the chemical composition, which lead to an increase in the fibre content.

\subsection{Juice Acidity}

Irrespective of the harvest date, the juice from the leaves and shoots of young barley had an acidic reaction (changes in $\mathrm{pH}$ are shown in Figure 3), shown by the significant decrease in $\mathrm{pH}$ values over time. The $\mathrm{pH}$ of the products pressed from leaves and shoots collected on day 7-28 ranged from 5.71 to 5.95. These values are similar to the $\mathrm{pH}$ of vegetable juices such as carrot or beetroot juice [21-23].

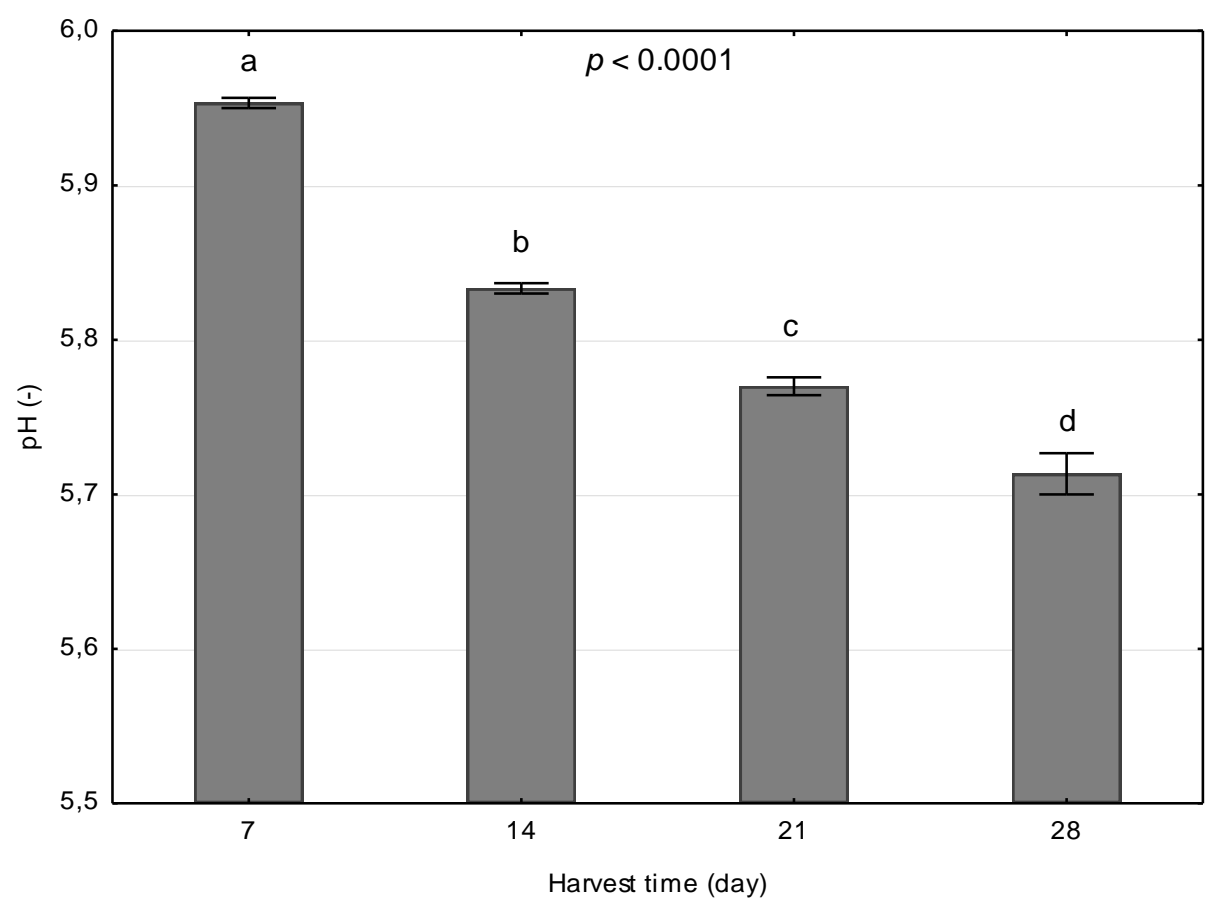

Figure 3. Impact of barley shoot harvesting time on juice $\mathrm{pH}$.

The $\mathrm{pH}$ values of the juice from young barley leaves did not change significantly during storage (Figure 4). The statistical analysis only revealed significant differences in the $\mathrm{pH}$ value in the case of juice refrigerated for seven days. The pasteurisation and freezing processes did not change this parameter significantly. Juice acidity has an important effect on pigments and other ingredients (e.g., chlorophyll, carotenoids, anthocyanins, myoglobin, etc.) responsible for the colour of fruits, vegetables, and meat $[21,24-26]$. 


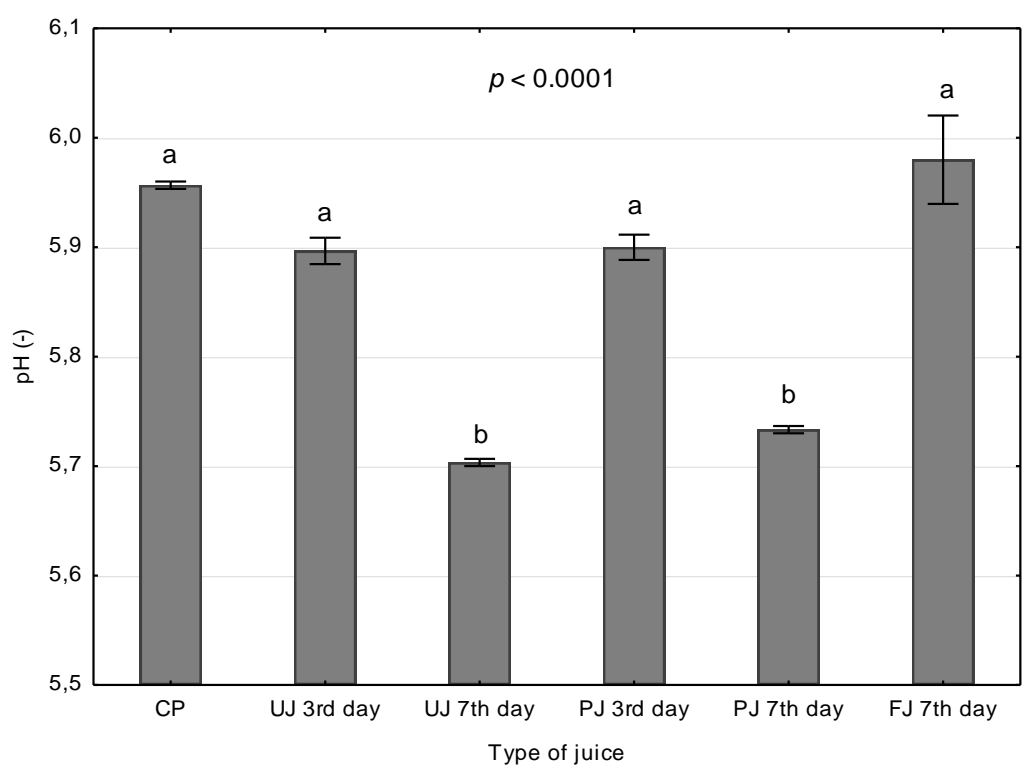

Figure 4. Impact of the conditions and length of storage on barley juice $\mathrm{pH}$. $(\mathrm{CP}-$ control probe for fresh juice, UJ—unprocessed juice, PJ—pasteurised juice, FJ—frozen juice; 3rd day—after three storage days, 7th day-after seven storage days).

\subsection{Total Protein Content}

Protein content was expressed as a percentage of dry matter, which was $4.71 \%$ on average. Changes in the protein content of the analysed juices are shown in Figure 5. The total protein content in the juice increased along with the barley harvest date. The differences in the protein content between the harvest dates were statistically significant. The highest protein content, i.e., 51\%, was determined in samples collected on day 21. The statistical analysis revealed that the content of this component in the juice produced after the next harvest (day 28) was significantly lower (42.68\%). As demonstrated by Pauličková et al. [2], the total amino acid content in juice from barley leaves and shoots decreased over time. The highest protein content recorded for the Malz cultivar (collected in phase I-DC 29) was $30.44 \%$ d.m. However, it should be noted that the authors collected the raw material at a later stage of barley growth. Therefore, these results may explain the lower protein content in the juice from barley leaves and shoots harvested on day 28 of growth (in comparison with the material obtained on day 21).

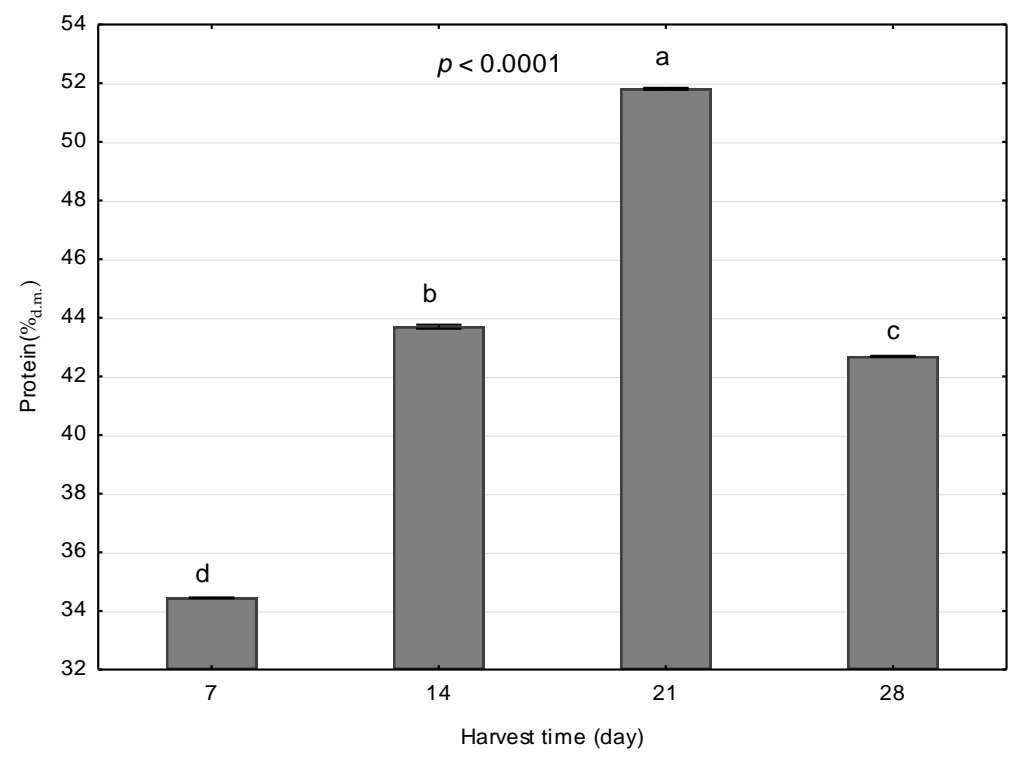

Figure 5. Changes in the protein content in barley shoot juice relative to the harvest date. 


\subsection{Chloride Content}

The changes in chloride content in the analysed juices are shown in Figure 6. The chloride content in the juices was positively correlated with the length of barley growth. The statistical analysis demonstrated statistically significant differences in this parameter between the harvest dates. The chloride content ranged from 0.021 to $0.117 \mathrm{~g} \cdot 100 \mathrm{~g}_{\mathrm{f.j}}{ }^{-1}$ for juice pressed from barley leaves and shoots collected on days 7-28. The increase in the chloride content was clearly correlated with a decrease in the $\mathrm{pH}$ of the juice. Park et al. [27] also showed that the amount of chlorides in the aboveground parts of plants may depend on the type of fertilization used.

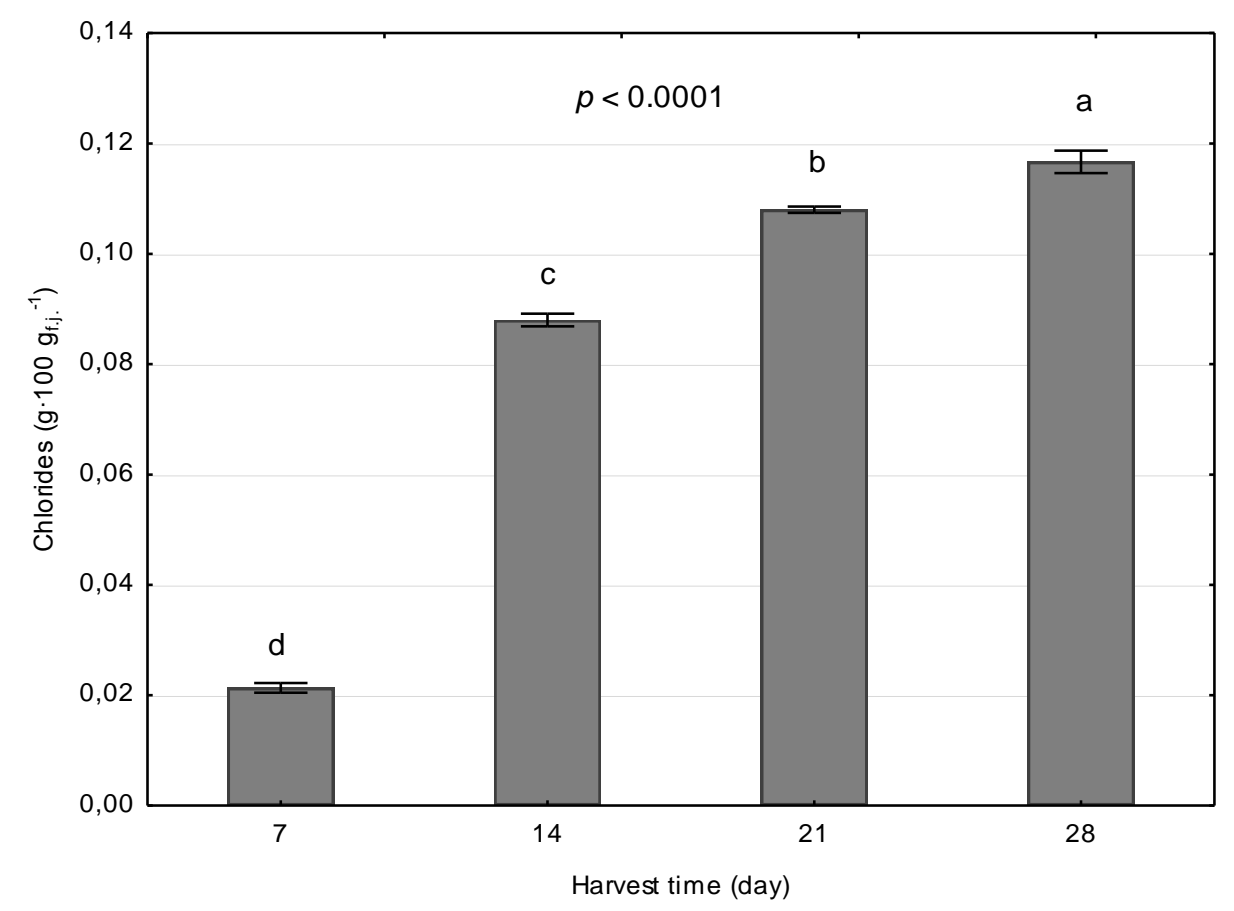

Figure 6. Changes in the chloride content in barley shoot juice relative to the harvest date.

\subsection{Content of Reducing Sugars}

Changes in the content of reducing sugars are shown in Figure 7. Their highest content was determined in the juice from barley leaves and shoots collected on day 21 of growth $\left(8.20 \mathrm{~g} \cdot 100 \mathrm{gd.m} .{ }^{-1}\right)$. The differences in the value of this parameter between products obtained from shoots collected on days 14 and 28 were not statistically significant. The statistical analysis confirmed the lower content of reducing sugars only for juice made from raw material collected on day 7 . The study conducted by Pauličková et al. [2] showed that the content of simple sugars varied, depending on the plant growth phase. Other factors that significantly determined the changes in the analysed parameter include the conditions of the soil and the variety of barley. Paulíčková et al. [2] demonstrated that the sugar content in most barley varieties steadily decreased throughout the growing season. 


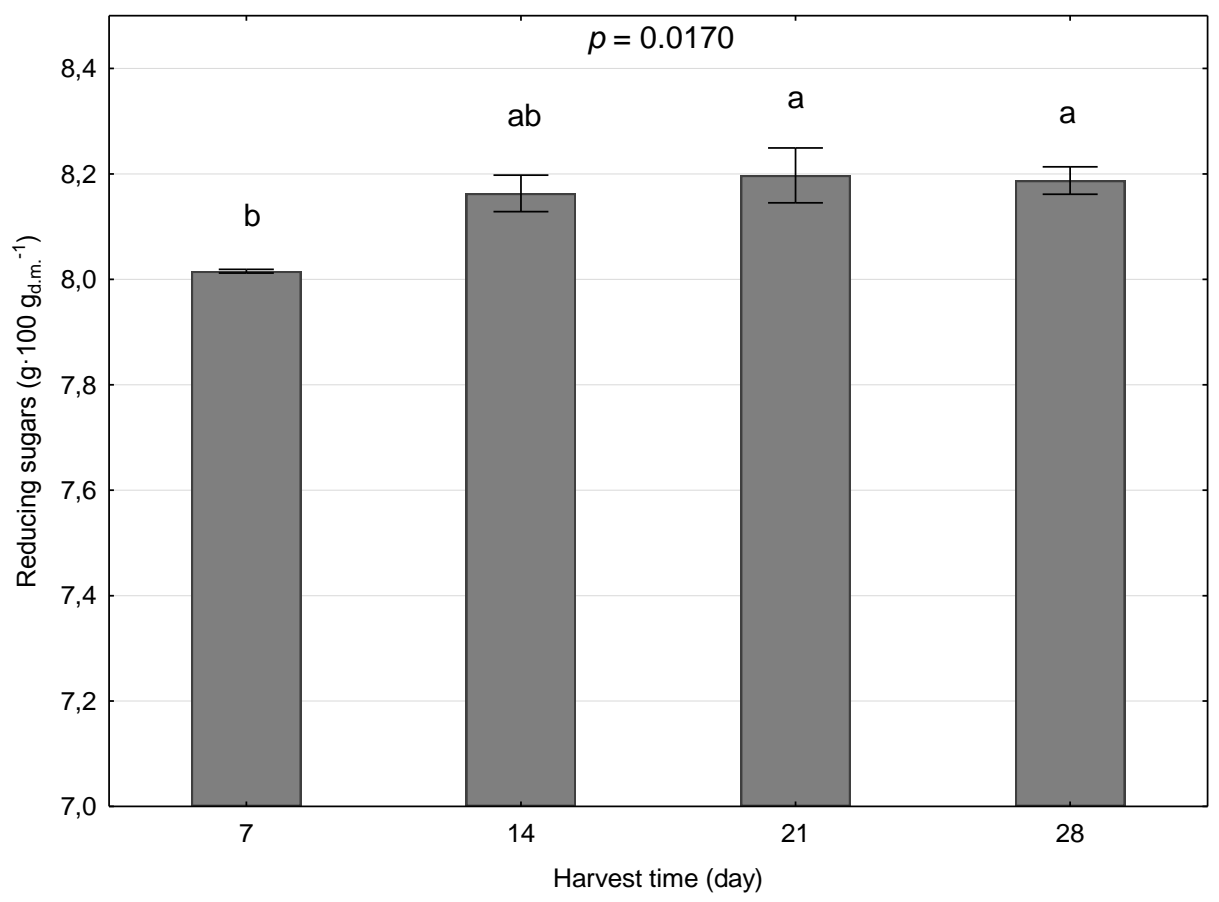

Figure 7. Changes in the content of reducing sugars in barley shoot juice, depending on the harvest date.

\subsection{Chlorophyll Content}

The chlorophyll content in the barley juice and the impact of the thermal treatment methods on changes in this parameter are shown in Table 2. The content of chlorophyll A and B and the total chlorophyll content changed significantly during storage. The highest determined content of total chlorophylls, i.e., $6.62 \mathrm{mg} / \mathrm{g}$, was found in fresh juice. The chlorophyll contents in fresh raw material obtained by other authors ranged from 10.15 to $19.62 \mathrm{mg} / \mathrm{g}[28,29]$. After seven days of storage, the total chlorophyll content was reduced by $37.9 \%$ (UJ), $42.12 \%$ (PJ), and $2.43 \%$ (FJ), in comparison with the untreated juice. It can thus be concluded from the present investigations that chlorophyll $\mathrm{A}$ is more sensitive to heat than chlorophyll B. Similar findings were reported by Weemaes et al. [30], who analysed the kinetics of chlorophyll degradation in thermally treated broccoli juice.

Table 2. Changes in the chlorophyll content in juice from young barley leaves during storage in various conditions $(p<0.0001)$.

\begin{tabular}{|c|c|c|c|c|c|c|}
\hline \multirow{2}{*}{$\begin{array}{c}\text { Type of Heat } \\
\text { Treatment/Ti-Me of Storage }\end{array}$} & \multirow{2}{*}{$\begin{array}{c}\text { Fresh } \\
\text { (Control Probe) }\end{array}$} & \multicolumn{2}{|c|}{ Unprocessed (UJ) } & \multicolumn{2}{|c|}{ Pasteurised (PJ) } & \multirow{2}{*}{ Frozen (FJ) } \\
\hline & & 3rd Day & 7th Day & 3rd Day & 7th Day & \\
\hline Chlorophyll A $\left(\mathrm{mg} \cdot \mathrm{g}^{-1}\right)$ & $4.80 \pm 0.01^{a}$ & $4.15 \pm 0.02^{c}$ & $2.99 \pm 0.01^{\mathrm{e}}$ & $3.80 \pm 0.00^{d}$ & $2.83 \pm 0.015^{f}$ & $4.66 \pm 0.01^{b}$ \\
\hline Chlorophyll B (mg.g $\left.{ }^{-1}\right)$ & $1.53 \pm 0.00^{\mathrm{a}}$ & $1.51 \pm 0.00 \mathrm{bc}$ & $0.85 \pm 0.01^{d}$ & $1.50 \pm 0.00^{\mathrm{c}}$ & $0.83 \pm 0.00{ }^{e}$ & $1.51 \pm 0.00^{b}$ \\
\hline Total chlorophylls $\left(\mathrm{mg} \cdot \mathrm{g}^{-1}\right)$ & $6.62 \pm 0.01^{a}$ & $6.02 \pm 0.04^{c}$ & $4.11 \pm 0.04^{\mathrm{e}}$ & $5.72 \pm 0.02^{d}$ & $3.83 \pm 0.007^{f}$ & $6.46 \pm 0.04^{b}$ \\
\hline
\end{tabular}

The process of freezing had the lowest effect on changes in the content of chlorophyll A and total chlorophylls. By contrast, in the case of chlorophyll B, the least significant changes were noted for the unpasteurised product refrigerated for one day and in the case of the frozen juice stored for seven days. Pauličková et al. [2] also confirmed the significant effect of thermal treatment of barley leaf juice (freezing, drying, and freeze-drying) on changes in the nutrient content. The analysis of their results also allows for the conclusion that freezing exerts the weakest effect on the quality of the product. Koca et al. [25] demonstrated a faster rate of degradation of chlorophylls at a lower $\mathrm{pH}$ value (from 5.5 to 7.5). Hence, the significantly lower chlorophyll content of juice stored for seven days may be caused by, e.g., changes in the $\mathrm{pH}$ of the product. 


\section{Conclusions}

The present investigations confirm the potential benefits of consuming green juice from young barley shoots and leaves as part of a daily diet. The product obtained from the material harvested after $7,14,21$, and 28 days of growth contains many valuable nutrients, e.g., a high level of total protein (with CS $=41.44$ Meth). Additionally, high pressing yields of approximately $70 \%$ can be achieved.

The study has demonstrated that barley leaves and shoots harvested on day 21 of plant growth are the best raw material for the production of juice. The process of pressing material collected at this time exhibits the highest efficiency, and the juice contains the highest levels of protein and reducing sugars, as well as a high chloride content.

The most effective way to preserve the juice from young barley leaves is freezing. This process does not induce changes in juice acidity and only slightly reduces the content of chlorophylls A and B during storage of the product. Pasteurisation of the juice significantly reduces the chlorophyll content, but does not induce statistically significant changes in the $\mathrm{pH}$ of the juice.

The reported results are a preliminary study on the topic. However, it is necessary to continue research to determine the impact of other factors (e.g., barley varieties, growing conditions) on the quality of juices from young barley shoots and leaves. It is also possible scale-up the experiment using a higher number of samples, filed conditions, etc.

In addition, this way of using shoots and leaves of young barley will have economic importance. The costs of obtaining raw materials for juice production will be reduced. The use of shoots and leaves of young barley, which is grown as a forecrop, for the production of green juices, may have a beneficial effect on the development of sustainable crop production. This will allow more efficient use of the plants.

Author Contributions: Conceptualization, A.B.-K., D.A., F.K. and L.R.; methodology, A.B.-K. and D.A.; formal analysis, A.B.-K. and F.K.; investigation, A.B.-K. and L.R.; data curation, A.B.-K. and L.R.; writing-original draft preparation, A.B.-K. and Z.K.; writing-review and editing, D.A.; visualization, A.B.-K.; supervision, D.A.

Funding: This research received no external funding.

Conflicts of Interest: The authors declare no conflicts of interest.

\section{References}

1. Jabłońska-Ceglarek, R.; Rosa, R. Forecrop green manures and the size and quality of white cabbage yield. Electron. J. Pol. Agric. Univ. 2003, 6. Available online: http://www.ejpau.media.pl/volume6/issue1/ horticulture/art-08.html (accessed on 21 July 2019).

2. PaulíčkoVá, I.; EhrENbErgEroVá, J.; FIEdlEroVá, V.; Gabrovska, D.; Havlova, P.; Holasova, M.; Vaculová, K. Evaluation of barley grass as a potential source of some nutritional substances. Czech J. Food Sci. 2007, 25, 65-72. [CrossRef]

3. Son, H.-K.; Lee, Y.-M.; Park, Y.-H.; Lee, J.-J. Effect of Young Barley Leaf Powder on Glucose Control in the Diabetic Rats. Korean J. Community Living Sci. 2016, 27, 19-29. [CrossRef]

4. Zeng, Y.; Pu, X.; Yang, J.; Du, J.; Yang, X.; Li, X.; Li, L.; Zhou, Y.; Yang, T. Preventive and Therapeutic Role of Functional Ingredients of Barley Grass for Chronic Diseases in Human Beings. Oxidative Med. Cell. Longev. 2018, 2018, 3232080. [CrossRef] [PubMed]

5. Barczak, B.; Nowak, K. Skład aminokwasowy białka biomasy jęczmienia ozimego (Hordeum vulgare L.) w zależności od stadium rozwoju rośliny i nawożenia azotem. Acta. Sci. Pol. Agric. 2008, 7, 3-15.

6. Jarosz, M.; Szponar, L.; Rychlik, E.; Wierzejska, R. Woda i elektrolity. In Normy Żywienia Dla Popul. Pol. Nowelizacja, 1st ed.; Jarosz, M., Ed.; Instytut Żywności i Żywienia: Warsaw, Poland, 2012; pp. 143-151.

7. García-Caparrós, P.; Almansa, E.M.; Chica, R.M.; Lao, M.T. Effects of Artificial Light Treatments on Growth, Mineral Composition, Physiology, and Pigment Concentration in Dieffenbachia maculata “Compacta” Plants. Sustainability 2019, 11, 2867. [CrossRef]

8. Kawka, K.; Lemieszek, M.K. Prozdrowotne właściwości młodego jęczmienia. Med. Ogólna I Nauk. O Zdrowiu 2017, 23, 7-12. [CrossRef]

9. Polak, R. Chlorofile jako naturalne źródło energii biomasy. Przemyst Chem. 2019, 1, 138-142. [CrossRef] 
10. Pradhan, J.; Das, S.; Das, B.K. Antibacterial activity of freshwater microalgae: A review. Afr. J. Pharm. Pharmacol. 2014, 8, 809-818.

11. Kandhasamy, S.; Chin, N.L.; Yusof, Y.A.; Lai, L.L.; Mustapha, W.A.W. Effect of Blender and Blending Time on Color and Aroma Characteristics of Juice and Its Freeze-Dried Powder of Pandanus amaryllifolius Roxb. Leaves (Pandan). Int. J. Food Eng. 2016, 12, 75-81.

12. Qamar, A.; Saeed, F.; Nadeem, M.T.; Hussain, A.I.; Khan, M.A.; Niaz, B. Probing the storage stability and sensorial characteristics of wheat and barley grasses juice. Food Sci. Nutr. 2019, 7, 554-562. [CrossRef] [PubMed]

13. Kubatka, P.; Kello, M.; Kajo, K.; Kruzliak, P.; Výbohová, D.; Šmejkal, K.; Maršík, P.; Zulli, A.; Gönciová, G.; Mojžiš, J.; et al. Young barley indicates antitumor effects in experimental breast cancer in vivo and in vitro. Nutr. Cancer 2016, 68, 611-621. [CrossRef] [PubMed]

14. Son, H.-K.; Lee, Y.-M.; Lee, J.-J. Nutrient Composition and Antioxidative Effects of Young Barley Leaf. Korean J. Community Living Sci. 2016, 27, 851-862. [CrossRef]

15. Majumdar, T.; Wadikar, D.; Vasudish, C.; Premavalli, K.; Bawa, A. Effect of Storage on Physico-Chemical, Microbiological and Sensory Quality of Bottlegourd-Basil Leaves Juice. Am. J. Food Technol. 2011, 6, $226-234$. [CrossRef]

16. Teixeira, E.M.B.; Carvalho, M.R.B.; Neves, V.A.; Silva, M.A.; Arantes-Pereira, L. Chemical characteristics and fractionation of proteins from Moringa oleifera Lam. leaves. Food Chem. 2014, 147, 51-54. [CrossRef]

17. Pielesz, A. Skład chemiczny algi brazowej Fucus vesiculosus L. Postępy Fitoter. 2011, 1, 9-17.

18. Briggs, D.E. Barley; Springer Science and Business Media: Berlin/Heidelberg, Germany, 2012; pp. 14-24.

19. Frank, A.B.; Bauer, A.; Black, A.L. Effects of Air Temperature and Fertilizer Nitrogen on Spike Development in Spring Barley. Crop. Sci. 1992, 32, 793-797. [CrossRef]

20. McMaster, G.S.; Wilhelm, W.W.; Frank, A.B. Developmental sequences for simulating crop phenology for water-limiting conditions. Aust. J. Agric. Res. 2005, 56, 1277-1288. [CrossRef]

21. Kırca, A.; Özkan, M.; Cemeroğlu, B.; Kirca, A.; Cemeroğlu, B. Effects of temperature, solid content and pH on the stability of black carrot anthocyanins. Food Chem. 2007, 101, 212-218. [CrossRef]

22. Nabrdalik, M.; Świsłowski, P. Microbiological Evaluation of Unpasterized Fruit and Vegetable Juices. In Proceedings of the ECOpole, Zakopane, Poland, 5-8 October 2016.

23. Yoon, K.Y.; Woodams, E.E.; Hang, Y.D. Fermentation of beet juice by beneficial lactic acid bacteria. LWT Food Sci. Technol. 2005, 38, 73-75. [CrossRef]

24. Czapski, J. Heat stability of betacyanins in red beet juice and in betanin solutions. Eur. Food Res. Technol. 1990, 191, 275-278. [CrossRef]

25. Koca, N.; Karadeniz, F.; Burdurlu, H.S. Effect of pH on chlorophyll degradation and colour loss in blanched green peas. Food Chem. 2007, 100, 609-615. [CrossRef]

26. Saguy, I. Thermostability of red beet pigments (betanine and vulgaxanthin-I): Influence of $\mathrm{pH}$ and temperature. J. Food Sci. 1979, 44, 1554-1555. [CrossRef]

27. Park, J.; Cho, K.H.; Ligaray, M.; Choi, M.-J. Organic Matter Composition of Manure and Its Potential Impact on Plant Growth. Sustainability 2019, 11, 2346. [CrossRef]

28. Cao, X.; Zhong, Q.; Wang, Z.; Zhang, M.; Mujumdar, A.S. Effect of microwave freeze drying on quality and energy supply in drying of barley grass. J. Sci. Food Agric. 2017, 98, 1599-1605. [CrossRef]

29. Cao, X.; Zhang, M.; Mujumdar, A.S.; Zhong, Q.; Wang, Z. Effect of nano-scale powder processing on physicochemical and nutritional properties of barley grass. Powder Technol. 2018, 336, 161-167. [CrossRef]

30. Weemaes, C.A.; Ooms, V.; Van Loey, A.M.; Hendrickx, M.E. Kinetics of Chlorophyll Degradation and Color Loss in Heated Broccoli Juice. J. Agric. Food Chem. 1999, 47, 2404-2409. [CrossRef]

C 2019 by the authors. Licensee MDPI, Basel, Switzerland. This article is an open access article distributed under the terms and conditions of the Creative Commons Attribution (CC BY) license (http://creativecommons.org/licenses/by/4.0/). 